\title{
How Indonesia Harmonize the International Trademark System
}

\author{
Bayu Sujadmiko ${ }^{1}$,Desi Churul Aini ${ }^{2}$, Muhammad Febriyan Saputra ${ }^{3}$ \\ \{bayu.sujadmiko@unila.ac.id ${ }^{1}$, desy.churulaini@fh.unila.ac.id ${ }^{2}$, muhammadfebriyan@yahoo.co.id ${ }^{3}$ \} \\ University of Lampung, Lampung, Indonesia ${ }^{1}$, University of Lampung, Lampung, Indonesia ${ }^{2}$, \\ University of Lampung, Lampung, Indonesia ${ }^{3}$
}

\begin{abstract}
World Intellectual Property Organization or commonly abbreviated as WIPO is an international organization that provides services, policies, information and cooperation in the field of intellectual property. At WIPO, trademarks can be registered through a system called the Madrid System or what is known as the International Trademark System. Indonesia itself is relatively new in implementing and following the provisions of the 1989 Madrid Protocol, namely on 30 September. In 2017, with the issuance of Government Regulation Number 92 of 2017 and starting to be implemented on January 2, 2018. The problem in this research is how to implement The International Trademark System in Indonesia. The method used is normative juridical. The implementation of The International Trademark System in Indonesia can be seen from changes in various aspects such as 1) legal aspects, 2) organizational aspects, 3) administrative aspects, 4) automation aspects, 5) education, through organizing seminars and technical guidance to interested parties.
\end{abstract}

Keywords: The International Trademark System, Trademark, World Intellectual Property Organization (WIPO).

\section{Introduction}

Trademark is a form of Intellectual Property Rights (IPR) which has an essential role in a product. The function of the trademark is as a means of trade promotion through advertising which is one way to attract consumers in expanding the product market. Trademarks also function as a liaison between goods and services with producers as a form of guarantee for the business reputation results in trade.[1] Besides, a trademark can be used as a characteristic to differentiate a product from another. A trademark can be used as a source of wealth that is commercially valuable, and often marks can increase the price of a product to high. [2] The high reputation and the massive attractiveness of the trademark in society will create the value of the trademark even higher.

The high trademark value in a particular product causes small traders who do not have their trademark, trying to find ways to remain competitive with the product. This market competition then triggers the emergence of various detrimental actions for the parties involved, such as plagiarism or imitating famous products in terms of packaging, logos and trademarks. According to the United States Trade Representative (USTR) Special 301 Report in 2019, Indonesia is one of the ten countries with the highest number of cases of intellectual 
property rights violations along with China, India, Algeria, Kuwait, Saudi Arabia, Russia, Ukraine, Argentina, Chile, and Venezuela. [3] The number of cases of plagiarism or imitating other products will harm the parties concerned so that a regulation is needed to protect intellectual property rights such as trademarks.

Protection of trademarks at the international level is stated in the Paris Convention for The Protection of Industrial Property 1883, and Trade-Related Aspects of Intellectual Property Right (TRIPS) 1995. At the national level, protection of well-known trademarks is contained in Law No. 20 of 2016 concerning Trademarks and Geographical Indications and Regulation of the Minister of Law and Human Rights No. 67 of 2016 concerning Trademark Registration. National laws and international laws governing trademarks confirm that to avoid plagiarism or imitating other products, trademarks must be registered with national channels, namely through related government agencies as well as through international channels, namely through the World Intellectual Property Organization (WIPO).

World Intellectual Property Organization or commonly abbreviated as WIPO is an international organization that provides services, policies, information, and cooperation on intellectual property. WIPO was formed in 1967 through the WIPO Convention, and currently, WIPO has 193 members. The mission of WIPO is to lead the development of a balanced and effective international intellectual property system by providing innovation and creativity for the common good. [4] At WIPO, trademarks can be registered through a system called the Madrid System or known as The International Trademark System. The Madrid System was formed based on two agreements, namely the Madrid Agreement Concerning The International Registration of Marks 1891 and The Protocol to that Agreement 1989. The cost required for trademark registration includes a basic fee of 653 Swiss francs or 903 Swiss francs for colour marks, plus additional fees depending on which trademarks want to be protected, and how many classes of goods and services will be protected. [5] Trademark registration through The International Trademark System can simplify trademark protection, because trademarks that have been registered will be automatically registered in several countries, thus simplifying and saving expenses. [6]

Indonesia itself is relatively new in implementing and acceding to the provisions of the 1989 Madrid Protocol, namely on September 30, 2017, with the issuance of Government Regulation No. 92 of 2017 and began to be implemented on January 2, 2018. [7] Therefore, the authors are interested in conducting further analysis on "Implementation of The International Trademark System in Indonesia". The problem that will be discussed is how is the implementation of The International Trademark System in Indonesia?

\section{Method}

This study uses a sociolegal approach and a statute approach as a qualitative research. The socio legal approach is used to examine the construction of functions, roles and communication processes of actors in issuing a policy, especially the mechanism regarding the registration process, recording and recognition of intellectual property. Meanwhile, the statutory approach is used to map the basis for government authority in accepting an international instrument into national law. National laws relating to intellectual property will be analyzed and harmonized with international policies and strategic steps that will be taken by the Indonesian government to protect these rights. 
This research was conducted in the ministry of law and human rights, especially at the director general of trademark and also at several multinational companies by means of interviews. Literature studies and case studies were also carried out in this research to see how the process of registration and dispute resolution was carried out by the parties.

\section{Discussion}

\subsection{Regulation of Trademark Registration in The International Trademark System}

Many countries, especially countries adhering to the civil law system [8], adhere to the first to file principle, namely that the right to a mark will be given to the owner who first applies for trademark registration. [9] This principle will encourage a trademark to be registered in order to grant rights to the mark. Besides, a trademark also adheres to a territorial principle that protection only applies in the country where the implementation for registration of a mark is filed. [10]

The existence of a territorial principle is considered inefficient because a trademark has to be registered in each country that wants protection, so a regulation is needed that can make trademark registration easier. The International Trademark System or also known as the Madrid System is an arrangement for registering and managing trademarks around the world by submitting a single implementation which can be valid in up to 122 countries. [11] The International Trademark System will make it easier and help trademark owners to protect their trademarks from various violations. However, this system does not replace the substance of the national trademark law in each country, but only as an alternative administrative procedure to be given to trademark owners who wish to register their trademarks abroad. In other words, this international route can be used side by side with the existing way of registering overseas marks. [12] In The International Trademark System, Applicants can choose for themselves in which countries the trademark wants to be protected by filling in the trademark implementation form and extending the protection to new areas that have not been selected. [13]. The mechanism of trademark registration in The International Trademark System or Madrid System can be described as follows: [14]

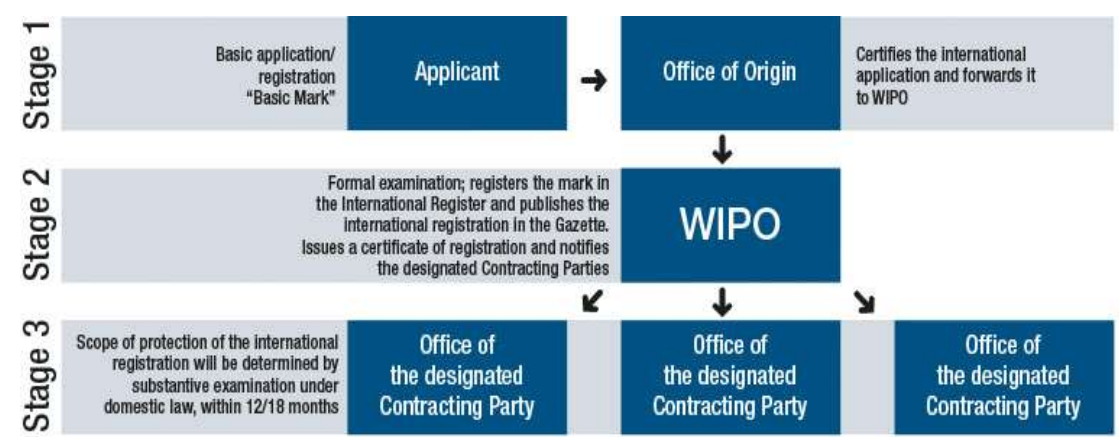

Fig. 1

Under this scheme, the trademark registration mechanism in The International Trademark System starts from the applicant submitting an implementation for international trademark registration to the trademark office of the country of origin. The trademark office of the 
country of origin will conduct a substantive examination of the implementation for registration of a mark. After validation and certification, international implementation for trademark registration is sent to WIPO. WIPO will conduct formalities check on the implementation. If approved, the mark will be registered in the international register and published in the WIPO Mark Sheet. The international registration certificate for marks sent by WIPO will be forwarded to the trademark office of the destination country. [15]

The trademark office of the destination country will decide within a time limit of 12 to 18 months in accordance with applicable law. WIPO will record the decision of the trademark office in an international register and then announce it to the applicant. If the trademark office refuses to protect the mark, either in total or in part, this decision will not affect the decision of the trademark office of another country. The applicant can oppose the decision to refuse the relevant trademark office in accordance with the law. If the implementation is accepted, the trademark office of the destination country will issue a statement regarding the granting of protection for the mark. International trademark registration is valid for ten years. The trademark owner can renew the registration at the end of the period every ten years to WIPO, which will take effect in the destination countries. [16]

Detailed trademark registration is regulated in article 3 Madrid Agreement Concerning The International Registration of Marks 1891 and article 3 The Protocol to that Agreement 1989 which states that every international implementation for trademark registration must state the date, filing number and date of filing for international registration of marks in accordance with the description in the national register. If the mark contains a colour that is characteristic of it, the applicant must attach a colour or a mixture of colours to his implementation. The applicant must show the goods or services as well as the classes according to the classifications stipulated by the Nice Agreement on the International Classification of Goods and Services for the Purpose of Registration of Marks. The international bureau will determine the classification of goods or services if the applicant does not provide an indication as stipulated. The national office will control the granting of class indications by the applicant, and in the event of disagreement between the national office and the international bureau, the final opinion will prevail. [17]

The Madrid Agreement on the International Registration of Marks 1891 and the Protocol to the Treaty 1989 also guide on matters relating to the registration of marks, namely as follows:

a) Refusal of Implementation

The trademark office of the destination country has the right to refuse registration or registration of a trademark registration for reasons that are contained in the Paris Convention. However, an implementation cannot be refused, a law that allows registration of a limited number of classes, goods or services. The trademark office wishing to exercise this right must notify the International Bureau with the reasons attached within 18 months. The International Bureau will send one of the notification notices to international registries. If the trademark office of the destination country does not notify the International Bureau of the reasons for refusing registration, the right to refuse the implementation may not be granted. [18]

b) Renewal of international trademark registration

Each registration can be renewed ten years from the previous expiration period, paying only the basic fee and / or additional and supplementary fees if required. This update may not cause changes in registration to the latest form. Six months before the end of the protection period, the trademark owner will send an unofficial notification by the International Bureau. The trademark owner will provide a grace period of six months for 
renewal of international registration by paying a supplementary fee in accordance with applicable regulations. [19]

c) International trademark registration fees

The trademark office of the country of origin can determine the fees required by the applicant for international registration or registration of trademarks. Registration of marks at the International Bureau is subject to an international fee which includes a basic fee, an additional fee for each class, and a supplementary fee for each request for extended coverage. [20]

The international trademark registration fee includes a basic fee of 653 Swiss francs or 903 Swiss francs for colour marks, plus additional fees depending on the area requested and the many classes of goods and / or services to be protected. Additional costs are also as needed after the trademark is registered, the owner wants to expand the geographic area, update or renew the trademark portfolio. [21] Supplementary fees will be reimbursed for "individual fees" [22] for countries that are already members of the Madrid agreement and the Madrid protocol. [23]

For example, if an applicant wants register a trademark without colour elements in Indonesia and the United States on March 7, 2020, for one class of goods, the total cost that should be paid 1,185 Swiss francs ( 653 basic costs +144 (one class in Indonesia) +388 (one class in the United States). The registration fees for all these countries are submitted to WIPO through the trademark office of the member country. [24]

\subsection{Implementation of the International Trademark System in Indonesia}

The implementation of The International Trademark System or also called Madrid System is still relatively new in Indonesia with the access to the 1989 Madrid Protocol on September 30, 2017, with the issuance of Government Regulation No. 92 of 2017 and began to be implemented on January 2, 2018. [25] The objectives for Indonesia to access the Madrid Protocol, namely: [26]

1) From a juridical perspective, Indonesia is committed to increasing trade cooperation with several countries that require acceding to the Madrid Protocol.

2) From an economic perspective, free trade makes Indonesia need reliable protection internationally, making it easier for trademark owners to develop their goods and / or services.

The International Trademark System in its implementation has many advantages compared to the national system registration system, which include: [27]

1) The International Trademark System makes national trademark registration more practical;

Table. 1 Comparison of National and International Trademark Registration Mechanisms [28]

\section{International route National route}
1) registered through one office of the original
1) register through many trademark offices mark
2) registered in one language, namely English
2) register with multiple languages
3) registered in 1 currency namely Swiss Francs
3) register with multiple currencies 

4) only through local agents in case of rejection
4) appointed multiple agents
5) results in one international registration
5) results in many national registrations
6) requires only one update
6) needs many updates
7) changes are recorded through the international bureau
7) changes are recorded through the respective national trademark offices

2) registration fee is more efficient because only one payment is required;

3) The registration time is shorter because only through international bureaus can a mark be registered in many countries;

4) There is a database of registered trademarks through The International Trademark System which can be accessed in detail and boldly on the WIPO website;

5) The trademark office will have revenue from the Individual Fee of the trademark registration;

As for the implementation of The International Trademark System there are several deficiency, namely: [29]

1) reliance on the principle (central attack) in the implementation of The International Trademark System to trademark registration;

2) For middle to lower trademark owners, this system is relatively expensive because there is an Individual Fee in each destination country;

3) There is a complete cancellation of the registration implementation if there is a cancellation of one class of goods or services in one implementation;

4) Limited protection in the country of destination due to more specific conditions in the country of origin.

Carlo Cotrone, an intellectual property expert who argues that harmonization of trademark law in which each jurisdiction is made substantially the same is impossible. The aim of the International Trademark System isn't judged to be the harmonization of law, but the "internationalization" of national law. That is, The International Trademark System must create a system whereby national legal entities can work concurrently (at least substantially) with the system. [30]

The existence of international registration depends on the first five years of basic registration. [31] If the basic registration does not exist before the end of that period (either because of a central attack or for other reasons depending on Article 6 (3) of the Madrid Protocol), the international registration will be cancelled. Furthermore, the scope of protection is limited to those imposed by the country of origin of the registrant. So, if membership in the country of origin cancels the registration, it will cancel the registration in other destination countries as well. This dependence, in Cotrone's view, violates the principle of national treatment by preventing applicants from obtaining the protection provided by local registrants. Thus, offering limits on trademark protection only makes individual national registrations more attractive so that individual countries can not only extend trademark protection but can also cancel marks based on its choice. [32]

The International Trademark System treats registrants differently depending on where they are from and which country they designate for protection. This system is more supportive 
of the laws of the country of origin than the parties appointed. This can be seen as a disadvantage for international applicants and as unfair treatment of a country's legal system, given the balance this system seeks to achieve. On the one hand, The International Trademark System must create an efficient administration system to serve trademark owners. However, on the other hand, the system cannot create creativity with the integrity of a party's legal system. In fact, The International Trademark System should support multiple systems side by side without substantial modification. [33]

The author states that Cotrone's statement is untrue. This system in replacement is not the substance of the national trademark law in each country, but only as an alternative administrative procedure to be given to trademark owners who want to mark overseas. In other words, this international route can be used side by side with the existing overseas trademark registration system. [34]

Since the accession of the Madrid Protocol in 1989, the International Trademark System has had many impacts on registration in Indonesia, both unfavourable and detrimental. The benefits include: [35]

1) Guaranteed credibility of Indonesia in the eyes of the world as a country that protects marks;

2) Increase investment from other countries in producing goods and / or services in Indonesia;

3) Increase non-tax state income through Individual Contribution obtained from the applicant country;

4) Owners of domestic product trademarks to save their trademarks so that they can compete at the international level.

The Madrid Protocol 1989 accession also did not escape the disadvantages of its implementation in Indonesia, which include: [36]

1) Lack of information regarding the mark in the destination country because there is no direct link to the local trademark office;

2) The existence of the principle of a central attack makes the owner disadvantaged because the country of origin rejects the proposed registration, the registration in other destination countries will also be cancelled;

3) Only shares that affect the change in ownership rights that can be made by the party having the right to apply for an international mark;

4) The loss of revenue from the IPR Consultant due to the registration of a trademark is carried out directly at the Trademark Office through the International Bureau. [37]

Apart from getting advantages and disadvantages, the effectiveness of the accession of The International Trademark System in Indonesia can also be seen through the implementation of the Madrid System in various aspects, namely: [38]

1) Legal aspects, the promulgation of Government Regulation No. 22 of 2018 and the publication of regulations regarding the Madrid System in Law No. 20 of 2016 concerning Trademarks and Geographical Indications, so that it makes registration simpler and the registration process shorter;

2) Organizational aspects, completion of the waiting list (backlog), the addition of the number of examiners, and orders for the Madrid Unit in Indonesia as the party responsible for implementing the Madrid System; 
3) Administrative aspects, operational procedures with the Madrid System, so that operational procedures are in accordance with the role of the Director-General of Intellectual Property as offices of countries of origin and offices of destination countries;

4) Automation aspects, through the development of the DGIP information technology system with the Industrial Property Automation System (IPAS), namely the system used by Madrid Union member countries for trademark registration, so that administrative activities can be carried out automatically;

5) Aspects of education, seminars through holding and technical guidance to interested parties.

Judging from the effectiveness of the implementation of the International Trademark System in Indonesia, it is argued that based on readiness and theory, having access to the International Trademark System has been implemented very well in Indonesia against the current trademark registration system. This can be seen from the changes in several aspects in accordance with The International Trademark System. Implementing this system does have its advantages and disadvantages. However, the author argues that the deficiencies in this system are not as many as the advantages obtained in the current implementation of The International Trademark System to trademark registration. So Indonesia's decision to accede to the 1989 Madrid Protocol is right, because this can make it easier for trademark owners and ensure Indonesia's credibility in the world.

\section{Conclusion}

Judging from the effectiveness of the implementation of The International Trademark System in Indonesia, the authors argue that based on the readiness and theory aspects, the effectiveness of the accession of The International Trademark System has been very well implemented in Indonesia for the current trademark registration system. This can be seen in its implementation in various aspects such as:

1) Legal aspects, through the promulgation of Government Regulation No. 22 of 2018 and the publication of the rules regarding the Madrid System in Law No. 20 of 2016 concerning Trademarks and Geographical Indications, so that it makes registration requirements simpler and the registration process shorter;

1) Organizational aspects, through completing the waiting list (backlog), increasing the number of examiners, and establishing a Madrid Unit in Indonesia as the party responsible for implementing the Madrid System;

2) Administrative aspects, through adjustments to operational procedures with the Madrid System, so that standard operating procedures are in accordance with the role of the Director-General of Intellectual Property as the office of the country of origin and the office of the country of destination;

3) Automation aspects, through the development of the DGIP information technology system with the use of the Industrial Property Automation System (IPAS), namely the system used by Madrid Union member countries for trademark registration, so that administrative activities can be carried out automatically;

4) Educational aspect, through holding seminars and technical guidance to interested parties. 
However, the implementation of The International Trademark System has several disadvantages, including:

1) Lack of information regarding the mark in the destination country because there is no direct link to the local trademark office;

2) The central attack principle causes the trademark owner to suffer losses because of the country of origin rejects the registration of a proposed mark, the registration in other destination countries will also be cancelled;

3) There are restrictions on changes in ownership rights that can only be made by parties who have the right to apply for international marks;

4) The loss of revenue from the IPR Consultant because the registration of a mark is carried out directly to the Trademark Office through the International Bureau.

However, the implementation of The International Trademark System in the trademark registration system has also provided benefits for Indonesia, such as:

1) Guaranteed credibility of Indonesia in the eyes of the world as a country that protects marks;

2) Increased investment from other countries in producing goods and / or services in Indonesia;

3) Increase non-tax state revenue through individual fees obtained from the applicant country;

4) Make it easier for domestic product trademark owners to register their trademarks so that they can compete at the international level.

Therefore, according to the author, Indonesia's decision to accede to the 1989 Madrid

Protocol is the right step to guarantee Indonesia's credibility in the world and help local trademark owners develop their trademarks to an international level.

\section{References}

[1] Madrid Agreement Concerning The International Registration of Marks (1891)

[2] Protocol Relating to The Madrid Agreement Concerning The International Registration of Marks (1989)

[3] Government Regulation No. 22/2018 concerning International Mark Registration Under the Protocol Related to the Madrid Agreement on International Registration of Marks

[4] United States Trade Representative (USTR) Special 301 Report in (2019)

[5] Madrid Protocol Handbook

[6] Agung Indriyanto.: Implementasi Protokol Madrid di Indonesia. Vol. 14. Edition 5. Directorate General of Intellectual Property (2017)

[7] Ariandika Herviandi, Etty Susilowati, and Rinitami Njatrijani.: Optimalisasi Perlindungan Hukum Terhadap Pendaftaran Merek Dagang di Negara Lain. Vol. 6. Number 1. Diponegoro Law Journal (2017)

[8] Deity Yuningsih.: The Legal Protection of Trademark Rights in the Judge's Decision of Indonesia. Vol. 61. Journal of Law, Policy, and Globalization (2017)

[9] Irna Nurhayati and Agustina Merdekawati.: Relevansi Keikutsertaan Indonesia Dalam International Registration Of Marks Madrid System Melalui Ratifikasi Madrid Protocol Terhadap Potensi Peningkatan Daya Saing Bangsa Indonesia Di Bidang Perdagangan Internasional. Volume 20. Number 3. Mimbar Hukum (2008) 
[10]I Made Dwi Prasetya and I Gede Putra Ariana.: Pengaturan Merek Produk Makanan (Berdasarkan Undang-Undang No. 20 Tahun 2016 Tentang Merek). Vol. 7. Number 1. Kertha Semaya: Journal Ilmu Hukum (2019)

[11]Jisia Mamahit.: Perlindungan Hukum Atas Merek pada Perdagangan Barang dan Jasa. Vol. I. No.3. Lex Privatum (2013)

[12]Nurul Hidayati and Naomi Yuli Ester S.: Urgensi Perlindungan Merek Melalui Protokol Madrid (Trademark Protection Urgency Through The Madrid Protocol). Vol. 14. No.2. Jurnal Indonesia Legislasi (2017)

[13]Peter Wilner.: Madrid Protocol: A Voluntary Model for the Internationalization of Trademark Law. Vol. 13. Number 3. De Paul Journal of Art, Technology and Intellectual Property Law (2016)

[14]Trias Palupi Kurnianingrum.: Pentingnya Ratifikasi Madrid Protocol Dalam Menghadapi Perdagangan Bebas Di Era Globalisasi. Vol. 7. No.2. Jurnal Penelitian Politik (2010)

[15]WIPO.: Protecting Your Brand Abroad. No. 1039E. WIPO publications (2013)

[16]Directorate General of Intellectual Property.: Pemanfaatan Sistem Madrid Untuk Pendaftaran Internasional Merek. Accessed from https://dgip.go.id/peman]-sistem-madrid-untuk-pend Registration-internasional-merek.

[17]The Union of Chambers and Commodity Exchanges of Turkey (TOBB). Introduce for the Madrid System. Accessed from http://abm.tobb.org.tr/haberler/fikrimulkiyet/1.

[18]WIPO.: About WIPO. Accessed from https://www.wipo.int/about-wipo/en/.

[19]WIPO.: Fees and Payments - Madrid System. Accessed from https://www.wipo.int/finance/en/madrid.html.

[20]WIPO.: How the Madrid System Works: The International Trademark Registration Process. Accessed from https://www.wipo.int/madrid/en/how_madrid_works.html.

[21]WIPO.: Madrid system. Accessed from https://www.wipo.int/madrid/en/.

[22]WIPO.: Madrid Union members. Accessed from https://www.wipo.int/madrid/en/members/. 